\title{
Health technology assessment of medical devices
}

\author{
Paweł Kawalec ${ }^{1}$ 으thps:/orid.orgy000-0002-0125-0947 \\ Magdalena Mrożek-Gąsiorowska ${ }^{1}$ (1) htpps///orid.org0000--003-1528-6876 \\ Ewa Stawowczyk ${ }^{2}$
}

\author{
${ }^{1}$ Instytut Zdrowia Publicznego Wydział Nauk o Zdrowiu, Uniwersytet Jagielloński Collegium Medicum, Kraków, \\ Polska \\ ${ }^{2}$ Akademia Techniczno-Humanistyczna, Bielsko-Biała, Polska
}

Address for correspondence: Paweł Kawalec, Instytut Zdrowia Publicznego, Grzegórzecka 20, 31-531 Kraków, pawel.kawalec@uj.edu.pl

\section{Abstract}

The current challenge for healthcare systems is to assess the clinical and economic value of non-drug technologies. Attempts have been made to use Health Technology Assessment, a standard method used in many countries to assess and make decisions regarding the reimbursement of medicines. The use of health technology assessment for non-drug technology can be a challenge because of the lower availability of high-quality scientific evidence in comparison with drugs. In several European countries attempts were made to develop guidelines for the clinical and economic evaluation of non-drug technologies; we presented specific guidelines prepared by British and French HTA agencies: NICE and HAS, respectively. In the case of Poland, the role of the Agency for Health Technology Assessment and Tariff System (AOTMiT) is to assess and appraise all medical technologies and services claiming public money funding; most of these assessments concern drug technologies. Only 103 of 1,550 orders (6.6\%) issued by the Ministry of Health, from $1^{\text {st }}$ January 2012 to $1^{\text {st }}$ July 2018, were related to non-drug technologies. The health services assessed by the AOTMiT include different non-drug medical technologies, both specialized medical devices as well as surgical interventions or diagnostic procedures or screenings. Orders for non-drug technologies issued by the Ministry of Health vary in scope and type of assessment.

\section{Key words:medilical devices, health technoloyy assessment, The Agency for Health Technology Assessment and Tariff System

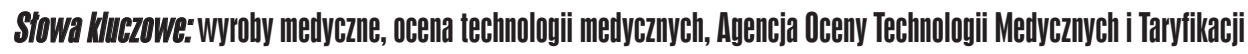

Ministerstwo Nauki i Szkolnictwa Wyższego
Przygotowanie do wydania elektronicznego finansowane w ramach umowy 641/P-DUN/2018 ze środków Ministra Nauki i Szkolnictwa Wyższego przeznaczonych na działalność upowszechniającą naukę.
In European Union countries, decisions for reimbursement of medicines are commonly based on the Health Technology Assessment (HTA); however, changes are happening much more slowly in the scope of legal regulations concerning requirements for introducing non-drug technologies (including medical devices) into the reimbursement list with the use of analogous tools.

Non-drug technologies can be of both therapuetic and diagnostic nature, or supportive in the case of disability. They include surgery techniques, intervention therapies (e.g. angioplasty) and medical devices (e.g. stents, cardiac pacemakers or orthopedic appliances).
The use of health technology assessment in relation to non-drug technologies can pose a challenge due to the quality of scientific evidence and the fact that such technologies may have various purposes and applications. Differences between the possibilities of assessing drug technologies and non-drug technologies result from the way the latter are marketed - namely, they do not require a presentation of detailed data derived from rigorously conducted clinical trials on efficacy and safety, nor undergo the admission procedure in the registration institution, as is the case with medicines [1]. 
The main problem with assessing non-drug technologies is the lower number of published scientific evidence (results of clinical trials). Moreover, there are fewer possibilities to compensate for high research costs of non-drug technologies with a short life cycle. What is more, the manufacturers of non-drug technologies, in contrast to pharmaceutical companies producing drugs, are mostly small entrepreneurs with small capital and limited experience in conducting clinical trials, and the problem is not only the small number of tests, but also their quality. Unlike in case of drugs, there are rare and usually methodologically limited clinical trials for non-drug technologies, and existing requirements in authorisation procedures are less challenging than those for drug testing. Available research for non-drug technologies often focuses on endpoints, the usefulness of which during clinical evaluation is limited; moreover, such studies are often planned without a control group [2].

Another problem when assessing non-drug technologies is the moment of their evaluation. These technologies are usually assessed in the initial phase of their lives, when the number of studies regarding their effectiveness is still very small. Therefore, data should be allowed from audits, unpublished studies ('data on file') or from conference abstracts, which may have lower reliability compared to randomized clinical trials, but on the other hand it will allow assessing the effectiveness of non-drug technologies.

Short product lifetime and frequent modifications (appearance of various types of these technologies) may affect the change in effectiveness and be a further impediment to a reliable clinical assessment for non-drug technologies. Similar technologies can also be produced by different manufacturers, further hindering their proper assessment.

It is not only the evaluation of clinical effectiveness (and safety profile) of non-drug technologies that is difficult to perform, but also the assessment of costs. The costs of non-drug technology are usually complex and consist of the cost of the technology itself and its implementation in patients and, importantly, they can change over time.

In contrast to drugs, in the case of non-drug technologies there are many additional factors that affect their effectiveness, including the conditions in which they are used, and the experience and competences of employees who operate or use them. This relationship is called 'learning curve' and should also be included in economic models used for non-drug technology assessments [1-4].

Non-drug technologies are evaluated in Polish conditions by the Agency for Health Technology Assessment and Tariff System (pol. Agencja Oceny Technologii Medycznych i Taryfikacji, AOTMiT) on the Ministry of Health (pol. Ministerstwo Zdrowia, MZ) order. However, the scale of such assessment is much lower than in the case of medicines. Between the year 2012 and $1^{\text {st }}$ July 2018 , the MZ issued to the AOTMiT a total of 1,550 orders, the vast majority of which $(91.2 \%)$ concerned drug technologies - mainly medicinal products, but also few special purpose dietary supplements. The aim of $33.4 \%$ of MZ orders was to prepare the AOTMiT verification analysis for drugs and to determine the official sales price. Other orders $(8.8 \%$ of all orders issued by MZ - 137 in total) included health services/non-drug technologies $(6.6 \%, 103$ orders), or concerned the preparation of the opinions on programmes, including national health programmes, issued mainly on the basis of Art. 48(2a) of the Act of 27 August 2004 on health care benefits financed from public funds (34 orders) (Figure 1) [5-9].

$\mathrm{MZ}$ orders regarding non-drug technologies were issued mainly on the basis of Art. 31c or Art. 31n(5) of the Act, or - though much less frequently - according to Art. 31e of the Act (7 MZ orders during the considered period) [5]. Among health care services assessed by the AOTMiT or still undergoing assessment, there are very diverse non-drug medical technologies, including technical medical devices, e.g. speech processors for brainstem implants or sound processors in auditory implants (MZ order no. 98/2018 of $1^{\text {st }}$ June 2018), as well as surgical interventions, such as prophylactic mastectomy in women with high to very high risk of breast cancer development (MZ order no. 39/2018 of $6^{\text {th }}$ February 2018) or diagnostic procedures, including the SATRO ECG diagnostic method based on ECG analysis and early detection of heart diseases (MZ order no. 4/2018 of $11^{\text {th }}$ January 2018) or screening tests (e.g. MZ order no. 47/2017 of $29^{\text {th }}$ March 2017), including evaluation of the screening system allowing for early diagnosis of cognitive deficiencies and dementia [5-9].

MZ orders concerning non-drug technologies vary in scope and cover different aspects of the assessment. Among MZ orders there are those covering only the preparation of a systematic review, i.e. the assessment of clinical effectiveness (e.g. MZ order no. 98/2018 indicated above) or orders regarding only the economic aspects, inluding budget impact (e.g. MZ order no. 132/2017 regarding the determination of the threshold price for cytological advice, preparation of supply and demand forecasts and the impact on the payer's budget), or covering the preparation of a report on the validity of qualifying for a guaranteed benefit package (e.g. MZ order no. 48/2017 regarding the evaluation of electroconvulsive therapy for patients with mental disorders) [5-9] (Table I).

In EU countries, methods of conducting advanced assessments of non-drug technologies are still being developed, and the agencies assessing medical technologies are using different ways to solve the problems that arise during the assessment. In 2009, the British National Institute for Health and Care Excellence (NICE), launched a Medical Technologies Evaluation Programme (MTEP) which aim was to identify new diagnostic technologies and procedures, evaluate them using standard NICE methods, and then, if necessary, introduce them into general use. A great number of subjects participated in the creation of the programme, including clinicians, patients' groups, representatives of the medical devices' manufacturers, payers, managers of medical services and the government. It was agreed that non-drug technologies should be compared with the current way of proceeding, 


$\begin{array}{r}400 \\ 300 \\ 250\end{array}$
200
150
100

Figure 1. MZ orders issued to AOTMiT in 2012 - H1 2018.

Source: Own calculations based on the data available on the AOTMiT website (http://www.aotm.gov.pl).

and the evaluation process should include two stages; firstly, it should be decided whether a given technology is worth further evaluation. Secondly, a detailed analysis should be carried out based on the cost-consequence model, which allows calculating whether a given technology generates savings in relation to the current care and how big are those savings. The manufacturer of a medical device should provide evidence not only that their product works, but that it is applicable in everyday practice and brings benefits for patients. The manufacturer should also define the current clinical practice that will be replaced or limited by the evaluated product. Different aspects are taken into account in the technology assessment, including: improving the health outcomes of patients, their quality of life or survival, decreasing the number of hospitalizations or shortening the time of hospitalization, the possibility of treating patients in an outpatient rather than inpatient setting, reducing the number of medical staffs' working hours as a result of the introduction of a given technology, and other factors affecting the reduction of costs, including costs of complications' treatment, transport and energy. The decision regarding the recommendation of a given technology largerly depends on the experts' opinion, but also on the opinion of patients and specialists in a given field $[2,10]$.

The solution used in Great Britain, concerned the non-drug technologies' assessment, deserves attention because it takes into account the most important aspects related to its application. Due to the lack of clinical trials for non-drug technologies or their low quality, the emphasis is placed on the opinion of clinical experts and other interested parties, in particular patients who can benefit from the introduction of a given technology. In contrast to drug technologies, non-drug technologies allow to perform the analysis based on conference-derived information, reports, or other publications that have significantly lower quality compared to randomized clinical trials conducted for medicines. In addition, as part of the economic assessment, the recommended analytical technique is the cost-consequence analysis, which is sufficient to indicate the possible savings generated by replacing the current practice with the assessed non-drug technology. Due to the fact that in the vast majority of cases a reliable comparison of the effectiveness of the assessed non-drug technology with current practice is not possible, great importance is attached to the assessment of the benefits that a given technology can bring to patients $[2,10]$.

A publication of the French agency specializing in the assessment of medical technologies, Haute Autorité de Santé (HAS), is also noteworthy as it presents an optimal methodology of clinical trials providing data on the effectiveness and safety of medical devices which are necessary to issue reimbursement decisions [11]. The requirements outlined are similar to those for medicines; however, it was distinguished into the evaluation of medical device with medical procedure which is needed for its use or the evaluation of the medical device solely. The document was prepared for manufacturers, research organizations and project creators. The aim of the study was to identify a set of methods and conditions that would allow high-quality clinical evaluation, especially when conventional randomized clinical trials cannot be performed. The review of comparative methods that can be used to assess the potential clinical benefits of non-drug technology should greatly facilitate the reimbursement process [11]. 


\begin{tabular}{|c|c|c|}
\hline $\begin{array}{l}\text { MZ order } \\
\text { number in } \\
\text { a given year }\end{array}$ & The scope of the MZ order & $\begin{array}{l}\text { Legal basis - Act on } \\
\text { healthcare services } \\
\text { financed from public } \\
\text { funds [6] }\end{array}$ \\
\hline \multicolumn{3}{|c|}{2018 (first half) } \\
\hline 2 & $\begin{array}{l}\text { Educational benefit in the field of diabetology in patients with diabetes, as a guaranteed benefit within } \\
\text { outpatient specialist care }\end{array}$ & Art. $31 \mathrm{c}$, section 1 \\
\hline 4 & $\begin{array}{l}\text { Diagnostic method of SATRO-ECG based on ECG analysis and early detection of heart disease as } \\
\text { a guaranteed benefit within primary health care }\end{array}$ & Art. $31 \mathrm{c}$, section 1 \\
\hline 5 & Corneal cross-linking surgery as a guaranteed benefit & Art. $31 \mathrm{n}(5)$ \\
\hline 6 & $\begin{array}{l}\text { Assessment of the quality and usefulness of scientific evidence in terms of its possible use as a source } \\
\text { of information for making a clinical decision on whether or not to use the therapy, based on the } \\
\text { webpage: www.haptens.republika.pl/haptenology pl.html }\end{array}$ & Art. $31 \mathrm{n}(5)$ \\
\hline 30 & $\begin{array}{l}\text { Preparation of recommendations of the Agency President regarding the justification of qualifying health } \\
\text { care benefits as guaranteed benefits, including an opinion on the genetic research financing model and } \\
\text { a proposal of conditions for the implementation in accordance with the recommended model of organi- } \\
\text { zation and financing of genetic research in outpatient health care: (1) A microarray-based Comparative } \\
\text { Genomic Hybridazation; (2) Gene expression profiling - various diagnostic sets dedicated to individual } \\
\text { cancers; (3) C-Ig-FISH (set of probes) (Cytoplasmic Immunoglobulin FISH) genetic test; (4) Analysis of } \\
\text { the expression of a gene or several genes (including fusion genes) using the real-time polymerase chain } \\
\text { reaction; (5) Whole-exome sequencing using the next-generation sequencing technology in diagnosing } \\
\text { genetically conditioned diseases; (6) BACS-on-Beads technology - in diagnosing prenatal abnormali- } \\
\text { ties of fetal development and structural defects; (7) Rapid-FISH (fluorescence in situ hybridization) in } \\
\text { diagnosing selected aneuploidies; (8) Clinical exom sequencing (panel of }>4,500 \text { genes with well-docu- } \\
\text { mented clinical significance) using the next-generation sequencing technology in diagnosing genetically } \\
\text { conditioned diseases; (9) Genetic test - (rapid, fluorescence in situ hybridization), prenatal test for aneu- } \\
\text { ploidy, set of probes; (10) MLPA (multiplex ligation-dependent probe amplification) in pre-natal digno- } \\
\text { stics; (11) Analysis of } 40 \text { or more amplicons or more than } 9 \text { kb of the coding sequence of the tested gene } \\
\text { or analysis of several genes or the use of microarrays (methylation, expression, chip-on-chip); } \\
\text { (12) Simple diagnostics not related to a specific disease entity (e.g. twins research, feedback analysis, } \\
\text { STR analysis - Short Tandem Repeat, VNTR - Variable Number Tandem Repeat) }\end{array}$ & Art. $31 \mathrm{c}$, section 1 \\
\hline 38 & $\begin{array}{l}\text { Treatment of diabetic foot syndrome as a guaranteed benefit within outpatient specialist care and } \\
\text { hospital treatment }\end{array}$ & Art. $31 \mathrm{c}$, section 1 \\
\hline 39 & $\begin{array}{l}\text { Prophylactic mastectomy in a group of women with high to very high risk of developing breast cancer } \\
\text { as a guaranteed benefit within hospital treatment }\end{array}$ & Art. $31 \mathrm{c}$, section 1 \\
\hline 40 & $\begin{array}{l}\text { Transurethral resection of a bladder tumour in blue light using a photosensitizer (TURBT-PDD) as } \\
\text { a guaranteed benefit within hospital treatment }\end{array}$ & Art. $31 \mathrm{c}$, section 1 \\
\hline 57 & $\begin{array}{l}\text { Assessment of the justification of changing the medical technology of all guaranteed services in the } \\
\text { areas of: basic health care, outpatient specialist care and hospital treatment }\end{array}$ & Art. 31(e) \\
\hline 72 & $\begin{array}{l}\text { (1) "Invasive pre-operative diagnostics to locate an epileptogenic focus - placement of intracranial } \\
\text { electrodes for long-term video-EEG monitoring"; (2)"The surgical procedure to remove an epilepto- } \\
\text { genic focus (one operation) with intraoperative EEG monitoring, electrocorticography with simultane- } \\
\text { ous functional brain monitoring (MEP, SSEP, BAEP), excitatory speech function", indication: epilepsy } \\
\text { (ICD-10: G40.0, G40.1, G40.2) as guaranteed benefits within hospital treatment }\end{array}$ & Art. $31 \mathrm{c}$, section 1 \\
\hline 73 & $\begin{array}{l}\text { Bronchial thermoplasty, indication: severe asthma as a guaranteed benefit in the field of hospital } \\
\text { treatment }\end{array}$ & Art. $31 \mathrm{c}$, section 1 \\
\hline 74 & $\begin{array}{l}\text { Daily long-term medical care as a guaranteed benefit within care and caring services as part of long- } \\
\text { term care }\end{array}$ & Art. $31 \mathrm{c}$, section 1 \\
\hline 82 & $\begin{array}{l}\text { Preparation of an analytical study on the possibility of using - in the ongoing programme of HBV and } \\
\mathrm{HCV} \text { prophylaxis - fast and cheap anti-HCV tests and tests confirming HBsAg, in which the blood is } \\
\text { collected for examination from the finger rather than from the vein }\end{array}$ & Art. $31 \mathrm{n}(5)$ \\
\hline 83 & $\begin{array}{l}\text { Evaluation of the justification of changing medical technology reagrding the definition of palliative } \\
\text { and hospice care as well as regarding the indications being the basis for qualifying for palliative and } \\
\text { hospice care }\end{array}$ & Art. $31 \mathrm{e}$ \\
\hline 86 & $\begin{array}{l}\text { Indication of the scope of convergence of recommendations and health care benefits included in the } \\
\text { "Guidelines for physicians referring patients for imaging", issued by the National Centre for Radio- } \\
\text { logical Protection in Health Care, with guaranteed benefits specified in the Regulation of the Minister } \\
\text { of Health of } 6 \text { November } 2013 \text { on guaranteed benefits within outpatient specialist care (Journal of } \\
\text { Laws of 2016, item 357, as amended) in Annex 2: list of guaranteed services in the case of diagnostic } \\
\text { tests and conditions for their implementation: computed tomography (part VI) and magnetic resonance } \\
\text { (part VIII) }\end{array}$ & Art. $31 \mathrm{n}(5)$ \\
\hline 89 & $\begin{array}{l}\text { Elaboration undergoing a consultation process involving a range of interested parties within the health } \\
\text { care system, appropriate solutions in the provision of comprehensive oncologic care in the field of } \\
\text { organ cancers, i.e. breast cancer, lung cancer, colon cancer, prostate cancer, gynecological oncology } \\
\text { (keeping in mind the schedule of works, adopted in the field of neoplastic diseases, taking into account } \\
\text { the development of recommendations, indicators, the project of the coordinating centre in a given area, } \\
\text { as well as a comprehensive guaranteed benefit) and preparation of the opinion of the Transparency } \\
\text { Council and Agency President, project of the coordinating centre in a given area, based on the dead- } \\
\text { lines defined in the attached schedule }\end{array}$ & Art. $31 \mathrm{n}(5)$ \\
\hline
\end{tabular}




\begin{tabular}{|c|c|c|}
\hline $\begin{array}{l}\text { MZ order } \\
\text { number in } \\
\text { a given year }\end{array}$ & The scope of the MZ order & $\begin{array}{l}\text { Legal basis - Act on } \\
\text { healthcare services } \\
\text { financed from public } \\
\text { funds [6] }\end{array}$ \\
\hline 92 & Evaluation of the justification of changing medical technology within medical rehabilitation & Art. $31 \mathrm{e}$ \\
\hline 97 & $\begin{array}{l}\text { Monitoring of L-asparaginase activity in patients with lymphoproliferative disorders. Indications } \\
\text { according to ICD-10 codes: C91.0, C83.0, C83.1, C } 83.2, \text { C } 83.3, \text { C } 83.4, \text { C } 83.5, \text { C } 83.6, \text { C } 83.7, \text { C } 83.8 \text {, } \\
\text { C83.9, C85, C85.0, C85.1, C85.7, C85.9 implemented as part of hospital treatment and outpatient } \\
\text { specialist care. }\end{array}$ & Art. $31 \mathrm{c}$, section 1 \\
\hline 98 & $\begin{array}{l}\text { Preparation of a systematic review and presentation of opinions on the clinical and practical effective- } \\
\text { ness and safety of speech processors in cochlear implants fixed to the brainstem of patients and sound } \\
\text { processors in other auditory implants. }\end{array}$ & Art. $31 \mathrm{n}(5)$ \\
\hline 101 & $\begin{array}{l}\text { Preparation of the opinion of the AOTMiT President regarding recommendations for the treatment and } \\
\text { diagnosis of breast cancer in the version from } 8 \text { June, } 2018 \text {. }\end{array}$ & Art. $31 \mathrm{n}(4 \mathrm{a})$ \\
\hline \multicolumn{3}{|c|}{2017} \\
\hline 21 & Cardiovascular diseases as a guaranteed benefit within primary health care & Art. $31 \mathrm{c}$ \\
\hline 33 & $\begin{array}{l}\text { Development of solutions in the scope of providing comprehensive oncologic care: "comprehensive } \\
\text { care for patients with breast cancer (Breast Cancer Unit)" }\end{array}$ & Art. $31 \mathrm{n}(5)$ \\
\hline 44 & $\begin{array}{l}\text { Indication of groups of medical devices constituting a significant cost of individual guaranteed } \\
\text { benefits, such as hospital treatment }\end{array}$ & Art. $31 \mathrm{n}(5)$ \\
\hline 47 & $\begin{array}{l}\text { The justification of introducing a screening system allowing for early diagnosis of cognitive disorders } \\
\text { and dementia }\end{array}$ & Art. $31 \mathrm{n}(5)$ \\
\hline 48 & $\begin{array}{l}\text { Preparation of a report on the justification of qualifying as guaranteed benefit in the field of psychi- } \\
\text { atric care and addiction treatment, the guaranteed benefit of electroconvulsive therapy for patients } \\
\text { with mental disorders [indication: life support] - to guaranteed benefit - electroconvulsive therapy for } \\
\text { patients with mental disorders }\end{array}$ & Art. $31 \mathrm{n}(5)$ \\
\hline 73 & $\begin{array}{l}\text { The justification of making changes in the description of the benefit "continuous glucose monitoring } \\
\text { system (CGM) in people with diabetes" }\end{array}$ & Art. $31 \mathrm{n}(5)$ \\
\hline 94 & $\begin{array}{l}\text { Recommendations for the diagnosis and treatment in the fields of: oncologic surgery, oncologic gyne- } \\
\text { cology, pediatric oncology and hematology, developed by relevant scientific societies }\end{array}$ & Art. $31 \mathrm{n}(4 \mathrm{a})$ \\
\hline 100 & Evaluation of fluoride prophylaxis & Art. $31 \mathrm{n}(5)$ \\
\hline 120 & $\begin{array}{l}\text { The justification of introducing diagnostic tests ordered by the doctor, anti-HCV examination and } \\
\text { defining a population in which it would be possible to perform the test according to the criteria } \\
\text { specified in the order }\end{array}$ & Art. 31 n (5) \\
\hline 132 & $\begin{array}{l}\text { Determination of the threshold valuation of cytological counselling carried out according to the sched- } \\
\text { ule of the prevention programme and early detection of cervical cancer; Preparation of the forecast of } \\
\text { supply and demand and the impact on the payer's budget, taking into account the assumption concern- } \\
\text { ing the estimated threshold valuation. }\end{array}$ & Art. 31 n (5) \\
\hline 141 & $\begin{array}{l}\text { Prophylactic removal of ovaries and fallopian tubes reducing the risk of ovarian and fallopian tube } \\
\text { cancer in carriers of pathogenic mutations in BRCA } 1 / 2 \text { genes as a guaranteed benefit in the field of } \\
\text { hospital treatment }\end{array}$ & Art. $31 \mathrm{c}$, section 1 \\
\hline 142 & $\begin{array}{l}\text { Care for the infertile couple as a guaranteed benefit within outpatient specialist care and hospital } \\
\text { treatment }\end{array}$ & Art. $31 \mathrm{c}$, section 1 \\
\hline 143 & $\begin{array}{l}\text { Peripheral angioplasty of the lower limbs (femoral and popliteal arteries) using the drug-eluting } \\
\text { balloon as a guaranteed benefit within hospital treatment }\end{array}$ & Art. $31 \mathrm{c}$, section 1 \\
\hline 160 & $\begin{array}{l}\text { Replacement of a subcutaneous implantable cardioverter-defibrillator as a guaranteed benefit within } \\
\text { hospital treatment }\end{array}$ & Art. $31 \mathrm{c}$, section 1 \\
\hline 175 & $\begin{array}{l}\text { Extension of the list of medical devices issued on behalf of a continuous glucose monitoring system } \\
\text { requiring the involvement of the patient without help or participation of professionals }\end{array}$ & Art. 31 n (5) \\
\hline 194 & $\begin{array}{l}\text { Liquid-based cytology as part of a cervical cancer prevention programme as a guaranteed benefit } \\
\text { within health programmess }\end{array}$ & Art. $31 \mathrm{c}$, section 1 \\
\hline 199 & $\begin{array}{l}\text { Qualification of healthcare benefit: "Dietary recommendation for pregnant women and parents, cus- } \\
\text { tomary primary carer or statutory representative of children from } 6 \text { months of age up to the age of 5", } \\
\text { as guaranteed benefits within health care and outpatient specialist care }\end{array}$ & Art. $31 \mathrm{c}$, section 1 \\
\hline 200 & $\begin{array}{l}\text { Evaluation of the justification of the change of medical technology regarding diagnostic tests of the CT } \\
\text { and MR within outpatient specialist care }\end{array}$ & Art. $31 \mathrm{c}$, section 1 \\
\hline 201 & $\begin{array}{l}\text { 1. Relaxing bite splint; } 2 \text {. X-ray diagnostics - pantomographic image with description once every } 5 \\
\text { years; } 3 \text {. Full upper overdentures based on protected roots; Full lower overdentures based on protected } \\
\text { roots, as guaranteed services in the field of dental treatment }\end{array}$ & Art. $31 \mathrm{c}$, section 1 \\
\hline \multicolumn{3}{|c|}{2016} \\
\hline 66 & $\begin{array}{l}\text { Percutaneous endoscopic gastrostomy - PEG for the purpose of nourishing a patient who cannot take } \\
\text { oral food, suffering from congenital disease associated with deficiency of clotting factors (haemophilia) } \\
\text { versus other possible ways of eating (e.g. nasogastric intubation, enteral feeding, parenteral nutrition } \\
\text { with a possible anticoagulant shield) }\end{array}$ & Art. $31 \mathrm{n}(5)$ \\
\hline
\end{tabular}




\begin{tabular}{|c|c|c|}
\hline $\begin{array}{l}\text { MZ order } \\
\text { number in } \\
\text { a given year }\end{array}$ & The scope of the MZ order & $\begin{array}{l}\text { Legal basis - Act on } \\
\text { healthcare services } \\
\text { financed from public } \\
\text { funds [6] }\end{array}$ \\
\hline 67 & $\begin{array}{l}\text { Preparation of an elaboration containing cost data and financial implications for the health care system, } \\
\text { in the part concerning the planned conditions for the performance of the service: Comprehensive treat- } \\
\text { ment of chronic and complicated wounds, including: wound dressing; relief; local pressure therapy; } \\
\text { antibiotic intravenous therapy; foot amputations; outpatient skin grafts; compression therapy. }\end{array}$ & Art. $31 \mathrm{n}(5)$ \\
\hline 150 & $\begin{array}{l}\text { Treatment of acute or chronic graft-versus-host disease (GvHD) resistant to corticosteroids using } \\
\text { extracorporeal photopheresis (ECP) }\end{array}$ & Art. $31 \mathrm{n}(5)$ \\
\hline 151 & Efficacy and safety of treatment of atherosclerosis in patients with chelatones (EDTA) & Art. $31 \mathrm{n}(5)$ \\
\hline 152 & $\begin{array}{l}\text { Qualifying as a guaranteed benefit in the field of hospital treatment a comprehensive project for the } \\
\text { care of patients following myocardial infarction }\end{array}$ & Art. $31 \mathrm{c}$ \\
\hline 153 & $\begin{array}{l}\text { Qualifying as a guaranteed benefit in the field of hospital treatment a comprehensive care project for } \\
\text { patients undergoing hip arthroplasty }\end{array}$ & Art. $31 \mathrm{c}$ \\
\hline 188 & $\begin{array}{l}\text { LDL-apheresis, used in homozygous or heterozygous hypercholesterolemia after } 3 \text { months of } \\
\text { ineffective treatment using diet and cholesterol-lowering drugs }\end{array}$ & Art. $31 \mathrm{n}(5)$ \\
\hline 196 & $\begin{array}{l}\text { Sleeve gastrectomy: Gastric bypass using the Roux-en-Y method; Gastric bypass using the mini gastric } \\
\text { bypass method - Surgical treatment of obesity. }\end{array}$ & Art. $31 \mathrm{c}$ \\
\hline 209 & $\begin{array}{l}\text { Assessment of the justification of qualifying for guaranteed benefits within palliative and hospice care } \\
\text { solutions in the scope of benefits for pregnant women with suspected fetal malformations, including } \\
\text { a presentation on the solutions }\end{array}$ & Art. $31 \mathrm{n}(5)$ \\
\hline 211 & $\begin{array}{l}\text { In cooperation with the Centre of Health Care Information Systems, developing an electronic base } \\
\text { of guaranteed benefits, which will be prepared in accordance with the structure of the description of } \\
\text { benefits accepted by the Minister of Health }\end{array}$ & Art. $31 \mathrm{n}(5)$ \\
\hline 212 & $\begin{array}{l}\text { Comparing the effectiveness of peritoneal dialysis with hemodialysis, and indicating whether there are } \\
\text { reasons to create conditions conducive to one of the methods. }\end{array}$ & Art. $31 \mathrm{n}(5)$ \\
\hline 215 & $\begin{array}{l}\text { In consultation with a group of interested parties within the health care system, proposing solutions } \\
\text { in the scope of medical rehabilitation benefits aimed at improving the availability of the benefits in } \\
\text { question }\end{array}$ & Art. $31 \mathrm{n}(5)$ \\
\hline 217 & Treatment of haemochromatosis with phlebotomy & Art. $31 \mathrm{n}(5)$ \\
\hline 218 & Detailed assessment of clinical, economic and budget impact of therapeutic hypothermia & Art. $31 \mathrm{n}(5)$ \\
\hline 219 & $\begin{array}{l}\text { Application of the da Vinci surgical system in the following indications: colorectal cancer, prostate } \\
\text { cancer, endometrial cancer }\end{array}$ & Art. $31 \mathrm{n}(5)$ \\
\hline 220 & Perinatal palliative care & Art. $31 \mathrm{c}$ \\
\hline \multicolumn{3}{|c|}{2015} \\
\hline 16 & Diagnosis and modification of treatment of patients with monogenic diabetes & Art. $31 \mathrm{c}$ \\
\hline 17 & $\begin{array}{l}\text { Continuous glucose monitoring system for people with diabetes (CGM) - as guaranteed benefits within } \\
\text { outpatient specialist care }\end{array}$ & Art. $31 \mathrm{c}$ \\
\hline 18 & Corneal cross-linking surgery (X-linking) & Art. $31 \mathrm{c}$ \\
\hline 19 & $\begin{array}{l}\text { Percutaneous balloon angioplasty of pulmonary arteries in the treatment of thromboembolic pulmonary } \\
\text { hypertension - as guaranteed benefits in hospital treatment }\end{array}$ & Art. $31 \mathrm{c}$ \\
\hline 29 & $\begin{array}{l}\text { Additional costs of continuous epidural anesthesia during delivery not included in the DRG [diagnosis- } \\
\text { related group; Pol. JGP] value presented by the NZF. This benefit is dedicated to aggregation with } \\
\text { groups JGP N01, N02, N03, N09, N11, N13 and will concern vaginal deliveries }\end{array}$ & Art. $31 \mathrm{n}(5)$ \\
\hline 31 & $\begin{array}{l}\text { Preparation of a short report on the inclusion of the diagnosis of multiple sclerosis (ICD-10: G35) into } \\
\text { the list of incurable, progressive life-limiting diseases in which guaranteed benefits in palliative and } \\
\text { hospice care are provided. }\end{array}$ & Art. $31 \mathrm{c}$ \\
\hline 69 & $\begin{array}{l}\text { Preparation of a short report regarding the qualification of the 'implantoprosthetic treatment' as a } \\
\text { guaranteed benefit for service recipients following surgical treatment of facial and cranial cancers in } \\
\text { the field of dental treatment. }\end{array}$ & Art. $31 \mathrm{c}$ \\
\hline 90 & $\begin{array}{l}\text { Proton radiotherapy of cancers located outside the eye, as a guaranteed benefit in the field of hospital } \\
\text { treatment, together with defining the qualification criteria, based on the principles of Evidence-based } \\
\text { Medicine, and establishing the cost of treatment }\end{array}$ & Art. $31 \mathrm{c}$ \\
\hline 110 & Treatment of adults with coma (underlying disease ICD-10 R40.2) & Art. $31 \mathrm{c}$ \\
\hline 111 & Determination of the cost rate for guaranteed health services in the field of dental treatment in children & Art. $31 \mathrm{n}(5)$ \\
\hline 113 & $\begin{array}{l}\text { Determining the cost rate of guaranteed health services in the field of imaging diagnostics performed in } \\
\text { children, which - for their proper implementation - require the use of anesthesia }\end{array}$ & Art. $31 \mathrm{n}(5)$ \\
\hline 115 & $\begin{array}{l}\text { Physiotherapy treatment performed at home - extending the period of service from } 6 \text { months to } 12 \\
\text { months, in the case of people who underwent fractures, injuries and amputations of the lower limbs, } \\
\text { referred to in } \S 6 \text {, section } 2.7 \text { of the MZ Regulation of } 6 \text { November, } 2013 \text { on guaranteed benefits within } \\
\text { medical rehabilitation (Journal of Laws, item 1522) }\end{array}$ & Art. $31 \mathrm{c}$ \\
\hline
\end{tabular}




\begin{tabular}{|c|c|c|}
\hline $\begin{array}{c}\text { MZ order } \\
\text { number in } \\
\text { a given year }\end{array}$ & The scope of the MZ order & $\begin{array}{c}\text { Legal basis - Act on } \\
\text { healthcare services } \\
\text { financed from public } \\
\text { funds [6] }\end{array}$ \\
\hline 116 & $\begin{array}{l}\text { Dental treatment under general anesthesia for uncooperative children, as part of the benefits included } \\
\text { in Annex } 3 \text { to the Ordinance of the Minister of Health of } 6 \text { November, 2013, regarding guaranteed } \\
\text { services in the field of dental treatment (Journal of Laws, item 1462) }\end{array}$ & Art. $31 \mathrm{c}$ \\
\hline 117 & $\begin{array}{l}\text { Adaptation visit for children under the age of } 4 \text {, as part of the benefits included in Annex } 3 \text { to the } \\
\text { Regulation of the Minister of Health of } 6 \text { November, } 2013 \text { on guaranteed benefits in the field of dental } \\
\text { treatment (Journal of Laws, item 1462) }\end{array}$ & Art. $31 \mathrm{c}$ \\
\hline 142 & $\begin{array}{l}\text { Combined therapy of mechanical clearing of intracerebral arteries with the administration of } \\
\text { a fibrinolytic medicine in the acute phase of ischemic stroke }\end{array}$ & Art. $31 \mathrm{c}$ \\
\hline 149 & $\begin{array}{l}\text { Analgesic treatment of drug-resistant bone metastases using non-invasive thermoablation with } \\
\text { a focused ultrasound beam under magnetic resonance control. }\end{array}$ & At. $31 \mathrm{c}$ \\
\hline 160 & Prophylactic dental care for children aged 3 & Art. $31 \mathrm{c}$ \\
\hline 168 & $\begin{array}{l}\text { Planning works on the verification of lists of guaranteed benefits included in the regulations of the } \\
\text { Minister of Health }\end{array}$ & Art. $31 \mathrm{n}(5)$ \\
\hline 212 & Bioresorbable technology in percutaneous coronary intervention & Art. $31 \mathrm{n}(5)$ \\
\hline 213 & $\mathrm{X}$-ray diagnostics for 5 intraoral images & Art. $31 \mathrm{c}$ \\
\hline 214 & Prophylactic protection of fissures with other materials & Art. $31 \mathrm{c}$ \\
\hline 215 & Endodontic treatment of a tooth with unformed root & Art. $31 \mathrm{c}$ \\
\hline 216 & Dental examination and check-up following tooth injury & Art. $31 \mathrm{c}$ \\
\hline 217 & Sealants in primary teeth & Art. $31 \mathrm{c}$ \\
\hline 218 & Prophylactic protection of fissures with dental sealants for second permanent molar teeth & Art. $31 \mathrm{c}$ \\
\hline 219 & X-ray diagnostics - pantomography image with description & Art. $31 \mathrm{c}$ \\
\hline \multicolumn{3}{|c|}{2014} \\
\hline 30 & Diagnosis of patients with syncope using an implantable arrhythmia recorder & Art. $31 \mathrm{n}(5)$ \\
\hline 185 & $\begin{array}{l}\text { Based on available HTA reports, indicating recommendations or experiences of international expert } \\
\text { circles, qualification criteria (or relative and absolute contraindications) for cataract surgery }\end{array}$ & Art. $31 \mathrm{n}(5)$ \\
\hline 236 & $\begin{array}{l}\text { Raising the age limit of children covered by the guaranteed benefit, titled 'prophylactic protection of } \\
\text { fissures with dental sealants - for each tooth' to the age of } 8\end{array}$ & Art. $31 \mathrm{f}$ \\
\hline \multicolumn{3}{|c|}{2013} \\
\hline 47 & Surgical treatment of colon cancer using a robotic system & Art. $31 \mathrm{c}$ \\
\hline 48 & Surgical treatment of prostate cancer using a robotic system & Art. $31 \mathrm{c}$ \\
\hline 49 & Surgical treatment of endometrial cancer using a robotic system & Art. $31 \mathrm{c}$ \\
\hline 56 & $\begin{array}{l}\text { Mechanical cardiac support with implantable pumps of the latest generation identified by highly } \\
\text { specialized procedures: } 13.1 \text { to } 13.5 \text { for highly specialized benefits }\end{array}$ & Art. $31 \mathrm{c}$ \\
\hline 209 & $\begin{array}{l}\text { Assessment of hyperbaric oxygen therapy in monoplace chambers and preparation of a summary report } \\
\text { in the subject area }\end{array}$ & Art. $31 \mathrm{n}(5)$ \\
\hline 217 & $\begin{array}{l}\text { Dental materials used to provide services for the beneficiaries, contained in Annex } 12 \text { to the Regulation } \\
\text { of the Minister of Health of } 30 \text { August } 2009 \text { on guaranteed benefits in the field of dental treatment } \\
\text { (Journal of Laws of } 2009 \text {, No. 140, item } 1144 \text { as amended) and the related financial consequences }\end{array}$ & Art. $31 \mathrm{n}(5)$ \\
\hline \multicolumn{3}{|c|}{2012} \\
\hline 10 & Selective Internal Radiation Therapy (SIRT) using Y-90 microspheres (SIR-Spheres) & Art. $31 \mathrm{n}(5)$ \\
\hline 15 & Hyperthermic intraperitoneal perfusion chemotherapy (HIPEC) & Art. $31 \mathrm{n}(5)$ \\
\hline 16 & Sanatorium / Spa treatment for adults & Art. $31 \mathrm{e}$ \\
\hline 17 & Spa rehabilitation for adults in a sanatorium & Art. $31 \mathrm{e}$ \\
\hline 32 & Hemodiafiltration (HDF) & Art. $31 \mathrm{c}$ \\
\hline 33 & Percutaneous renal denervation (PRD) in the treatment of resistant hypertension & Art. $31 \mathrm{c}$ \\
\hline 38 & $\begin{array}{l}\text { Rehabilitation of a patient following a stroke, with upper limb spasticity, treated with topical adminis- } \\
\text { tration of botulinum toxin, which will be carried out under the conditions specified in the order }\end{array}$ & Art. $31 \mathrm{c}$ \\
\hline 94 & $\begin{array}{l}\text { Treatment of acute or chronic graft-versus host disease [GvHD] resistant to corticosteroids, using } \\
\text { extracorporeal photopheresis [ECP] }\end{array}$ & Art. $31 \mathrm{c}$ \\
\hline 95 & Hybrid cardiac rehabilitation & Art. $31 \mathrm{c}$ \\
\hline 99 & $\begin{array}{l}\text { Change in financing both lungs transplantation in adults and children with cystic fibrosis - option } 3.3 \\
\text { as a variant, highly specialized benefit No. } 3 \text { 'lung transplantation', financed from the state budget at } \\
\text { the disposal of the minister competent for health }\end{array}$ & Art. $31 \mathrm{n}(5)$ \\
\hline
\end{tabular}




\begin{tabular}{|l|l|l|}
\hline $\begin{array}{c}\text { MZ order } \\
\text { number in } \\
\text { a given year }\end{array}$ & \multicolumn{1}{|c|}{ The scope of the MZ order } & $\begin{array}{c}\text { Legal basis - Act on } \\
\text { healthcare services } \\
\text { financed from public } \\
\text { funds [6] }\end{array}$ \\
\hline 100 & $\begin{array}{l}\text { Separating new variants: } \\
\text { 1) lung transplantation in patients with primary pulmonary hypertension }-3.4 ; \\
\text { 2) transplantation of both lungs in patients with primary pulmonary hypertension }-3.5 ; \\
\text { - as variants of 3.4 and 3.5, highly specialized benefit No. 3 'lung transplantation', financed from the } \\
\text { state budget at the disposal of the minister competent for health }\end{array}$ & Art. 31 n (5) \\
\hline 101 & $\begin{array}{l}\text { Qualifying as a guaranteed benefit a highly specialized benefit; mechanical cardiac support with the } \\
\text { latest generation of implantable pumps, identified using highly specialized procedures: } 13.1 \text { to } 13.5\end{array}$ & Art. 31 n (5) \\
\hline 119 & $\begin{array}{l}\text { Transcatheter non-operational mitral valve repair (MitraClip) in high-risk patients, } \\
\text { implemented in the scope of highly specialized benefits }\end{array}$ & Art. 31 c \\
\hline
\end{tabular}

Nevertheless, the abovementioned methods have their limitations and should be reserved for unique situations where a traditional randomized clinical trial cannot be performed. In this situation, the inference regarding clinical effectiveness can be based on reports of lower reliability, also observational studies. All the same, randomized clinical trials remain the preferred standard for assessing the effectiveness of prophylaxis or therapy using medical devices [11].

The Medical Technology Assessment Guidelines, issued by AOTMiT in the year 2016, apply only to drug technologies [12]. However, there are no Polish guidelines for non-drug technology assessment that would contain detailed rules defining the method and scope of this assessment.

It seems that also in Polish conditions it would be useful to develop transparent and reliable principles used in the assessment of medical devices, including the methods of health technology assessment. Guidelines for the assessment of medical devices corresponding to those developed for drug technologies would allow to determine the optimal standard of data needed to demonstrate the effectiveness, safety and cost-effectiveness of medical devices, and explain how deviations from these standards affect the assessment of specific products.

\section{References}

1. Keltie K., Bousfield D.R., Cole H., Sims A.J., Medical Technologies Evaluation Programme: A review of NICE progression decisions, 2010-2013, "Health Policy and Technology" 2016; 5: 243-250.

2. Campbell B., NICE medical technologies guidance: Aims for clinical practice, "Perioperative Medicine" 2013; 2: 15.
3. Campbell B., Campbell M., NICE Medical Technologies Guidance a Novel and Rigorous Methodology to Address a New Health Technology Assessment Challenge, "Appl. Health Econ. Health Policy" 2012; 10 (5): 295-297.

4. Campbell B., Dobson L., Higgins J. et al., A new health technology assessment system for devices: the first five years, "International Journal of Technology Assessment in Health Care" 2017; 33 (1): 19-24.

5. Ustawa $z$ dnia 27 sierpnia 2004 r. o świadczeniach opieki zdrowotnej finansowanych ze środków publicznych (Dz.U. 2004 Nr 210 poz. 2135 z późn. zm.).

6. Agencja Oceny Technologii Medycznych i Taryfikacji, Zlecenia MZ 2012-2015; http://bipold.aotm.gov.pl/index.php/ zlecenia-mz-2012-2015 (accessed: 10.10.2018).

7. Agencja Oceny Technologii Medycznych i Taryfikacji, Zlecenia MZ 2016; http://bipold.aotm.gov.pl/index.php/ zlecenia-mz-2016 (accessed: 10.10.2018).

8. Agencja Oceny Technologii Medycznych i Taryfikacji, Zlecenia MZ 2017; http://bipold.aotm.gov.pl/index.php/ zlecenia-mz-2017 (accessed: 10.10.2018).

9. Agencja Oceny Technologii Medycznych i Taryfikacji, Zlecenia MZ 2018; http://bipold.aotm.gov.pl/index.php/ zlecenia-mz-2018 (accessed: 10.10.2018).

10. Medical Technologies Evaluation Programme, Methods guide, NICE, April 2011.

11. Fournel I. et al., Methodological Choices for the Clinical Development of Medical Devices, "Medical Devices" (Auckland, N.Z.) 2014; 7: 325-334.

12. AOTMiT, Wytyczne oceny technologii medycznych (HTA, ang. health technology assessment), wersja 3.0, Agencja Oceny Technologii Medycznych i Taryfikacji, Warszawa sierpień 2016. 